\title{
A REVIEW ON INDIAN TRIBAL PLANTS AND THEIR BIOGENIC PROPERTIES
}

\author{
ANJU K, ANITHA JEGADEESHWARI L, VIDHYA LAKSHMI D, NAGENDRA GANDHI N*
}

Department of Chemical Engineering, ACT Campus, Anna University, Chennai - 600 025, Tamil Nadu, India. Email: nagendragandhi.n@gmail.com

Received: 29 December 2017, Revised and Accepted: 11 January 2018

\begin{abstract}
Green synthesis of silver nanoparticles (AgNPs) is considered to be nature-friendly and risk-free to the ecosystem. India is copious in biodiversity; the traditional medicine consists of the plant as a major component. The tribal people who lived in the rural region are entirely dependent on the tribal plant for their medical emergencies. These tribal plants have attracted the modern drug industry to develop drugs which are economical with minimal side-effects. The present study focuses on the tribal plants such as Aegle marmelos, Andrographis paniculata, Acacia arabica, Ficus religiosa, Cassia auriculata, Punica granatum, and Tinospora cordifolia used by the Bhilla, Irular, Dimasa, Paliyan Sholaga, and Dantewada tribes of India for their antimicrobial activity. Since these tribal plants are well known for its medicinal properties, the AgNPs synthesized from these plants were found to have enhanced antimicrobial activity than the pure plant extract.
\end{abstract}

Keywords: Green synthesis, Silver nanoparticles, Tribal plants, Antimicrobial.

(C) 2018 The Authors. Published by Innovare Academic Sciences Pvt Ltd. This is an open access article under the CC BY license (http://creativecommons. org/licenses/by/4. 0/) DOI: http://dx.doi.org/10.22159/ajpcr.2018.v11i4.24474

\section{INTRODUCTION}

Ancient Greeks, Romans, and Egyptians considered silver has one of the potent agents and used it to preserve food and water due to its excellent antimicrobial properties. Hence, it was the third metal used by them next to gold and copper [1]. In addition, silver has been used in the traditional Ayurvedic medicine around 2000 years ago as silver ash, its colloidal and suspended form to restore the body. Even silver nitrate was used in medicine as wound healing, counterirritant, purgative, and also to treat brain infections [1,2]. Rajata, another name for silver during ancient Acharyas was used from the time of Charaka and is included in Charaka Samhita, a scheduled book of Ayurveda. Due to its clear, lustrous properties and due to its genuine properties such as bright whitening of metal during heating or cutting without any formation of furrows and ridges makes it valuable in therapeutics [3]. Rajata Bhasma was found to be effective in the enhancement of immune system due to its high solubility, absorbance, and catalyzing effect on the body $[3,4]$.

Nanotechnology is important in modern research due to its nano-sized particle ranging from 1 to $100 \mathrm{~nm}$ and its wide range of applications in medicine [5,6] as theranostic agents [7], in delivering ocular drugs to the target site in ophthalmology [8], as nanoparticle-assisted drug delivery to the skin as it can act as route for delivery of local and systematic drug, as anti-inflammatory drugs, antiphotoaging drugs, antioxidants, antimicrobial agents $[9,10]$, targeted chemotherapeutic agent, and nanodots are used [11]. In food industry, nanoparticles are employed to detect contaminants or microbes present in packed foods and also to prevent obesity in the form of nanofoods [12]. Nano-enabled water and wastewater systems can increase the treatment efficiency of alternative water resources [13]. It is also used in the textile industry especially due to its high durability for fabrics, excellent protection from ultraviolet rays, anti-static property and has good resistance to wrinkles of cotton and silk [14]. In the agricultural field, nanomaterials can be used to improve the efficiency of seed germination, to protect the plants by detecting the pathogens and pesticide residue [15]. Also used in electronic storage systems [16].

Metallic nanoparticles, in the form of colloids or sols, are used for ornamental decorations by the middle ages [17] are of noble metal nanoparticles (NMNs) and non-NMNs. Noble metals include ruthenium $(\mathrm{Ru})$, rhodium $(\mathrm{Rh})$, palladium $(\mathrm{Pd})$, silver $(\mathrm{Ag})$, osmium $(\mathrm{Os})$, iridium (Ir), platinum (Pt), and gold $(\mathrm{Au})$ where these metals are inert and hence resistant to corrosion unlike non-noble metal [18]. Among these metals gold $(\mathrm{Au})$, silver $(\mathrm{Ag})$, and platinum $(\mathrm{Pt})$ has unique and adjustable electrical, optical, structural parameters (size, shape, composition, surface) and chemical properties, high surface area, good stability, and good biocompatibility. Since NMNs consists of better selectivity and activity than transition metals, it can be used in many environmental applications $[19,20]$. Non-noble metals can be used along with noble metal to synthesize bimetallic nanoparticle which has high catalytic activity [21] and has the potential for adapting the electron distribution of alloy nanoparticles. Non-noble metals also have some less expensive metals such as $\mathrm{Fe}, \mathrm{Co}, \mathrm{Ni}$, and $\mathrm{Cu}$ has been developed for the dehydrogenation of ammonia borane [22].

Silver as a noble metal has its origin from ancient time has rich esthetic and medicinal values, where it is known by different names such as Dutch (zilver), German (Silber), and Anglo-Saxon (seolfor), Greek (Argyros), Latin (argentums), Italian (Argento), French (argent) and Spanish (Plata). In addition, silver is used in bone prostheses, ophthalmic surgery, veterinary medicine, desalination of seawater, and as active adsorbent [18]. It is believed that colloidal form of silver has the high germicidal activity such as antibacterial, antifungal, antiseptics, and no toxicity against humans [23]. Due to its antifungal property, silver nanoparticles (AgNPs) are extensively used to prevent biofouling on the surface of the cathode [24]. AgNPs has gained boundless interest due to their unique properties such as chemical stability $[25,26]$, good conductivity $[27,28]$, catalytic [29] and most important antibacterial [30,16] antifungal [31], antiviral, [32-34] and anti-inflammatory activities [35-37]. In addition, silver has occupied a major place in consumer products where some of the products are toothpaste, as an engineered nanomaterial get exposed to environment and makes available for humans through drinking water, humidifiers, and through soil $[38,39]$, it is used in clothing to protect from body odor, medicine such as acne creams and sulfadiazine creams, cosmetics, baby pacifiers, washing machine, and electronic gadgets [40]. The AgNPs used in industry for developing commercial products found to contain AgNP in their wastewater and it was found that its presence does not affect the chemical oxygen demand removal [41]. 
Table 1: Synthesis of AgNPs using different parts of tribal plants

\begin{tabular}{|c|c|c|c|c|}
\hline S. No & $\begin{array}{l}\text { Tribal plant } \\
\text { name }\end{array}$ & Part used & Characterization & Inference \\
\hline \multirow[t]{2}{*}{1} & A. marmelos & Leaf & UV- 420 nm; XRD-fcc; FTIR & Antimicrobial action against $B$. subtilis and P. aeruginosa \\
\hline & & Fruit & $\begin{array}{l}\text { UV- } 421 \mathrm{~nm} \\
\text { XRD- } 24 \mathrm{~nm}\{\mathrm{fcc}\} \\
\text { TEM- } 18-30 \mathrm{~nm} \\
\text { HRTEM- } 24 \mathrm{~nm} \\
\text { CV analysis- peaks at }-0.31 \\
\text { and } 0.10 \mathrm{~V}\end{array}$ & $\begin{array}{l}\text { Antibacterial activity against } E \text {. coli, } B \text {. cereus, } S \text {. } \\
\text { aureus, } P \text {. aeruginosa was carried on and the maximum } \\
\text { antibacterial activity was observed against } B \text {. cereus }\end{array}$ \\
\hline \multirow[t]{2}{*}{2} & A. paniculata & Leaf & $\begin{array}{l}\text { UV- } 410 \mathrm{~nm} \text {; } \\
\text { XRD-fcc; } \\
\text { SEM- } 35-55 \mathrm{~nm} \text {, spherical; } \\
\text { EDX }\end{array}$ & $\begin{array}{l}\text { Antiplasmodium activity against } P \text {. falciparum revealed } \\
\text { lowest inhibition rate at IC50, } 25 \mu \mathrm{g} / \mathrm{ml}(20 \%) \text { and highest } \\
\text { inhibition at } 100 \mu \mathrm{g} / \mathrm{ml}(83 \%)\end{array}$ \\
\hline & & Whole plant & $\begin{array}{l}\text { UV- } 430 \mathrm{~nm} \text {; } \\
\text { SEM- } 40-80 \mathrm{~nm} \text {, spherical; } \\
\text { TEM-14-26 nm; FTIR }\end{array}$ & $\begin{array}{l}\text { Antibacterial activity against } S \text {. aureus, P. aeruginosa and } \\
\text { E. coli. } \\
\text { Antifungal activity against A. niger and not on A. flavus }\end{array}$ \\
\hline \multirow[t]{2}{*}{3} & A. arabica & Gum & $\begin{array}{l}\text { UV-462 nm; } \\
\text { SEM- spherical, } 35 \mathrm{~nm} \text {; } \\
\text { XRD- crystalline; } \\
\text { SAED- 94\%; ICP-AES }\end{array}$ & $\begin{array}{l}\text { AgNPs synthesized were effective against both } B \text {. subtilis } \\
\text { and } P \text {. aeruginosa. Where, AgNPs is more potent against } \\
\text { Gram-positive than Gram-negative bacteria }\end{array}$ \\
\hline & & Bark & $\begin{array}{l}\text { UV- } 430 \mathrm{~nm} \text {; } \\
\text { TEM- } 40-55 \mathrm{~nm} \text {; } \\
\text { XRD- Fcc, } 45 \mathrm{~nm} \text {; } \\
\text { SEM-Spherical, } 40-50 \mathrm{~nm} \text {; } \\
\text { FTIR; EDX }\end{array}$ & $\begin{array}{l}\text { Antimicrobial activity against } S \text {. aureus and } P \text {. aeruginosa, } \\
\text { which showed potential antibacterial activity against } \\
\text { S. aureus }\end{array}$ \\
\hline \multirow[t]{2}{*}{4} & F. religiosa & Leaf & $\begin{array}{l}\text { UV- } 430 \mathrm{~nm} \text {; } \\
\text { SEM- spherical, } 5-50 \mathrm{~nm} \text {; } \\
\text { XRD- fcc, } 4 \mathrm{~nm} \text {; } \\
\text { AFM-W= } 280 \mathrm{~nm}, \mathrm{~T}=4 \mathrm{~nm} \text {; } \\
\text { EDX; FTIR }\end{array}$ & $\begin{array}{l}\text { FESEM and AFM confirms the particles are polydispersed. } \\
\text { The reduction of silver ions and stabilization of the AgNPs } \\
\text { was due to the participation of quinones and flavonoids }\end{array}$ \\
\hline & & Latex & UV- $422 \mathrm{~nm}$ & $\begin{array}{l}\text { AgNP were collected from latex of } 6 \text { different plant where } \\
\text { among them F. religiosa ranks } 3 \text { rd depending on the size } \\
\text { of AgNP }\end{array}$ \\
\hline \multirow[t]{2}{*}{5} & C. auriculata & Leaf & $\begin{array}{l}\text { UV- } 450 \mathrm{~nm} \text {; } \\
\text { XRD-Fcc, } 20.84 \mathrm{~nm} \text {; } \\
\text { SEM-spherical, 20-40 nm; } \\
\text { FTIR }\end{array}$ & $\begin{array}{l}\text { The synthesized AgNPs are stable where the control of } \\
\text { shape and size of AgNP is easy due to selection of plant leaf } \\
\text { extract }\end{array}$ \\
\hline & & Flower & $\begin{array}{l}\text { UV- } 436 \mathrm{~nm} \text {; } \\
\text { TEM-circular distribution, } \\
\text { spherical, } \\
\text { XRD- } 50-70 \mathrm{~nm} \text {, } \\
\text { FCC; FTIR }\end{array}$ & $\begin{array}{l}\text { The synthesized AgNP exhibited antibacterial activity } \\
\text { against } S \text {. typhi, K. pneumonia, E. faecalis and E. coli, except } \\
\text { S. aureus }\end{array}$ \\
\hline \multirow[t]{5}{*}{6} & P. granatum & Seed & $\begin{array}{l}\text { UV- } 472 \mathrm{~nm} \text {; } \\
\text { XRD- Fcc, } 10-30 \mathrm{~nm} \text {; } \\
\text { SEM-nano flower and } \\
\text { spherical, } 10-30 \mathrm{~nm} \text {; EDX; } \\
\text { FTIR }\end{array}$ & $\begin{array}{l}\text { AgNPs produced showed effective antibacterial activity } \\
\text { against B. cereus with } 14 \mathrm{~mm} \text { zone of inhibition than } \\
\text { Pseudomonas, S. albus, Proteus }\end{array}$ \\
\hline & & Fruit peel & $\begin{array}{l}\text { UV- } 448 \mathrm{~nm} \text {; } \\
\text { XRD- Fcc, } 15-35 \mathrm{~nm} \text {; } \\
\text { SEM- nanoflower and } \\
\text { spherical, } 10-30 \mathrm{~nm} \text {; EDX; } \\
\text { FTIR }\end{array}$ & $\begin{array}{l}\text { AgNP produced is effective against } \text { B. cereus with } 17 \mathrm{~mm} \\
\text { inhibition zone than Pseudomonas, S. albus, Proteus. }\end{array}$ \\
\hline & & Leaf & UV- $400 \mathrm{~nm}$ & $\begin{array}{l}\text { Antibacterial activity against B. cereus, Pseudomonas, } \\
\text { S. aureus were studied } \\
\text { Also antifungal activity against C. albicans and Aspergillus } \\
\text { was studied }\end{array}$ \\
\hline & & Flower & UV-450 nm & $\begin{array}{l}\text { Antibacterial activity against B. cereus, Pseudomonas, and } \\
\text { S. aureus were studied. Where Staphylococcus showed } \\
\text { maximum inhibition zone } \\
\text { Also antifungal activity against C. albicans and Aspergillus } \\
\text { was studied }\end{array}$ \\
\hline & & Fruit & UV- $490 \mathrm{~nm}$ & $\begin{array}{l}\text { Antibacterial activity against } B \text {. cereus, Pseudomonas, and } S \text {. } \\
\text { aureus were studied } \\
\text { Also antifungal activity against } C \text {. albicans and Aspergillus } \\
\text { was studied }\end{array}$ \\
\hline
\end{tabular}


Table 1: (continued)

\begin{tabular}{|c|c|c|c|c|}
\hline S. No & $\begin{array}{l}\text { Tribal plant } \\
\text { name }\end{array}$ & Part used & Characterization & Inference \\
\hline \multirow{4}{*}{7.} & \multirow{4}{*}{$\begin{array}{l}\text { T. cordifolia } \\
\text { Tinospora } \\
\text { cordifolia }\end{array}$} & Exocarp & UV- 556 nm; FTIR; PCA & $\begin{array}{l}\text { Antimicrobial activity was exhibited against } E \text {. coli, } \\
\text { P. aeruginosa and P. vulgaris, zones of inhibitions } 8-16 \mathrm{~mm}\end{array}$ \\
\hline & & Mesocarp & UV- 506 nm; FTIR; PCA & $\begin{array}{l}\text { Antimicrobial activity was exhibited against E. coli, } \\
\text { P. aeruginosa and P. vulgaris, zones of inhibitions } 9-16 \mathrm{~mm}\end{array}$ \\
\hline & & Leaf & $\begin{array}{l}\text { UV- } 430 \mathrm{~nm} \text {; } \\
\text { XRD- } 24 \mathrm{~nm} \text {, fcc; SEM- } \\
\text { spherical; EDX; FTIR }\end{array}$ & $\begin{array}{l}\text { The AgNPs produced from the plant showed high } \\
\text { antibacterial activity against both Gram-positive and } \\
\text { Gram-negative bacteria than the pure plant extract. } \\
\text { The AgNPs produced showed high activity against } \\
\text { Staphylococcus sp. and Klebsiella sp. than Bacillus sp. }\end{array}$ \\
\hline & & Stem & $\begin{array}{l}\text { UV- } 420-425 \mathrm{~nm} ; \quad \text { TEM- } \\
\text { spherical, } 36 \pm 9 \mathrm{~nm} ; \\
\text { XRD- } 12.49 \mathrm{~nm} \text {; FTIR; EDX }\end{array}$ & $\begin{array}{l}T \text {. cordifolia acts as very good multi fdrug resistant agent } \\
\text { against } P \text {. aeruginosa }\end{array}$ \\
\hline
\end{tabular}

UV-Vis: Ultraviolet-visible, FTIR: Fourier transforms infrared, EDX: Energy dispersive X-ray, SEM: Scanning electron microscopy, TEM: Transmission electron microscopy, XRD: X-ray diffractometer, FCC: Face-centered cubic, CV: Cyclic voltammetry, HRTEM: High-resolution transmission electron microscopy, SAED: Selective area electron diffraction, ICP-AES: Inductively coupled plasma atomic emission spectroscopy, AFM: Atomic force microscopy, W: Width, T: Thickness, PCA: Principal component analysis. AgNPs: Silver nanoparticles, A. marmelos: Aegle marmelos, A. paniculata: Andrographis paniculata, A. Arabica: Acacia Arabica, F. religiosa: Ficus religiosa, C. auriculata: Cassia auriculata, P. granatum: Punica granatum, T. cordifolia: Tinospora cordifolia, B. subtilis: Bacillus subtilis, P. aeruginosa: Pseudomonas aeruginosa, E. coli: Escherichia coli, B. cereus: Bacillus cereus, S. aureus: Staphylococcus aureus, P. falciparum: Plasmodium falciparum, A. flavus: Aspergillus flavus, A. niger: Aspergillus niger, S. typhi: Salmonella typhi, K. pneumonia: Klebsiella pneumonia, E. faecalis: Enterococcus faecalis, S. albus: Staphylococcus albus, C. albicans: Candida albicans, P. vulgaris: Pseudomonas vulgaris

\section{SYNTHESIS OF AGNPS}

AgNPs can be synthesized by several methods. Among the huge number of methods available in physical method evaporation-condensation and laser ablation approaches are commonly used to produce large quantities of AgNPs. However, this method is not widely used due to its time-consuming procedure, expensive equipment, and high operating conditions [5]. In the case of chemical synthesis of AgNPs many methods are available such as chemical reduction method, polyol method, radiolytic method and much more. In comparison with the physical method, by chemical method AgNPs can be produced at low cost, simple equipment and in high yield. The three major components involved in the chemical synthesis process are the metal precursor, reducing agents (organic and inorganic), stabilizing, or capping agents $[42,43]$. These components used are of toxic and hazardous chemicals and they contain potential environmental risks [42].

Whereas the green synthesis method is a quick process, economic, safe to environment, and humans [44]. Some of the green synthesis methods involve polysaccharide method, irradiation method, biological method, polyoxometalates method, and tollens method. The biological method is mostly used one where its sources consist of plants, algae, diatoms, bacteria, yeast, fungi, and human cells $[44,45]$. Plant-mediated synthesis is an attractive method for nanoparticle synthesis and considered as the best option among other biological methods due to its effective inhibitory action against extensive drug resistance microbes [46]. In addition, nanoparticles can be synthesized at ambient temperature, low cost, short production time, and in large volume [44]. Here, due to the presence of phytochemicals, the silver nitrate will be reduced to AgNPs where the biomolecules present in it act as both reducing and capping agent, making the process easy and reliable $[47,48]$.

\section{TRIBAL PLANTS}

There are various tribal communities worldwide who lives as scattered and small groups in the plains, forest, hills, and distant areas from the mainstream population. Their social, cultural, and economic patterns differ from one region to another. The largest tribal population was found in India which comprises $8.6 \%$ of the total population of the country. India consists of 29 states and 7 union territories where the tribal population of India belongs to three races, namely, the protoaustraloids, the mongoloids, and the negritos. In addition, the Indian tribes have been denoted by different names such as Vanyajati (caste of the forest), Vanavasi (inhabitants of forest), Pahari (hill dwellers), Adimjati (primitive people), Girijan (hill dwellers), Anusuchit Jan Jati (scheduled tribe) [49-51].

These indigenous people maintain a close relationship between the man and the surroundings and hence found to have great knowledge on the use of plants to cure various diseases, where nearly 6500 plants were used by the traditional healers in Southeast Asia. The documentation of the tribal plants and its traditional uses as medicine has conquered the modern drug industry, where the inborn antimicrobial activity of the tribal plant can be enhanced by its respective synthesis of AgNPs [52-54], These tribal plants can also act as a potent source to develop anticancerous and antibiological drugs with low or no side effects for the user [55].

\section{Aegle marmelos}

1. Kingdom: Plantae

2. Family: Rutaceae

3. Genus: Aegle

4. Species: A. marmelos.

A. marmelos is a subtropical species which can adopt a wide range of habitat and hence can be cultivated worldwide. It is native to India and the tree grows wild in dry forest of central and southern India, Burma, Pakistan and Bangladesh, it is also grown in Nepal, Myanmar, Tibet, Ceylon, Vietnam, Laos, Cambodia, Sri Lanka, Thailand, Indonesia, Malaysia, Surinam, Trinidad and Northern Luzon of Philippine Islands. A. marmelos is a slow-growing, medium-sized tree which can grow up to 12-15 m tall. It has a short trunk, and its bark is thick, soft, flaking, and spreading. The wood of this tree is used as carts and for construction purposes. From the wounded branches, the gum is discharged slowly which tastes sweet first and irritating to the throat later. This gum is used as adhesives. The leaves are deciduous, arranged in an alternate fashion where $4-10 \mathrm{~cm}$ long and $2-5 \mathrm{~cm}$ wide oval, pointed, shallowtoothed leaflets are present. These leaves cause sterility in women and its extract consists of insecticidal activity against brown planthopper. The tree produces fragrant flowers in the month of April and May with green outside and yellow inside along the young branches. The fruits produced were found to be edible and have different shapes such as oval, flat, spherical, oblong, and pear grows up to $5-20 \mathrm{~cm}$ in diameter. The fruit has thin hardy shell gray-green outside where it takes 1011 months to ripen and appears yellowish in color $[56,57]$ 
The Bael tree is considered as one of the most sacred trees of India [58]. A. marmelos is used by the Bhilla tribe of Maharashtra to treat snake bite. The snake-bitten part is treated by applying the leaf juice and in case of nausea, squeezed leaves are swallowed [59]. The chemical constituents present in the different parts of this tree are alkaloids, coumarins and steroid [58]. Due to the presence of various phytochemical constituents, it is used in Ayurveda and in ethnomedicine since it has potent antibacterial, antifungal, antiviral, antioxidant, anticancer, antiulcer, antipyretic, analgesic, antispermatogenic, antidiabetic, antiinflammatory, and antihyperlipidemic activities [58,60,61].

\section{Andrographis paniculata \\ 1. Kingdom: Plantae \\ 2. Family: Acanthaceae \\ 3. Genus: Andrographis \\ 4. Species: A. paniculata.}

A. paniculata also known as the king of Bitters is an annual herb cultivated in tropical and sub-tropical Asia, Southeast Asia, India, China, America, West Indies, Bangladesh, Hong Kong, Pakistan, Philippines, Malaysia, Indonesia, and Thailand. A. paniculata is an herbaceous plant which grows in moist shady places to a height of $30-110 \mathrm{~cm}$. The stem of this plant is tetrangular in shape with glandular hairs outside. The leaves are green or copper shade arranged in a simple, opposite decussate fashion of $6-10 \mathrm{~cm}$ long and width of $3.5-5 \mathrm{~cm}$. The flowers are the complete one, bisexual in nature, hypogynous, pentameric, and appear pinkish violet in color. Fruits are dry dehiscent, flat capsules with length $12-17 \mathrm{~mm}$ and width $2-3.5 \mathrm{~mm}$, on maturity it appears as dull brown in color. The three layers in the root are packed together with visible secondary growth. The root and leaf are the major parts used in the traditional medicine $[62,63]$. The Irular tribe who resides in the Kadambur hills in sathyamangalam forest of Erode district in Tamil Nadu uses the leaf extract of $A$. paniculata for Snakebite, Chicken kunai, and Cancer [64]. in addition, this plant is used in the traditional medicine to treat skin infections, respiratory diseases, herpes, dysentery, fever, sore throat, lower urinary tract infections, and diabetes and to reduce inflammation. The bitter and cold property of this herb is considered in the traditional Chinese medicine, and hence, it serves as a remedy for acute infections such as tonsillitis, gastroenteritis, pyelonephritis, and pneumonia [65]. The phytochemicals found in the A. paniculata are a lot of terpenoids such as diterpenoid lactones and various other compounds like flavonoids such as flavones; xanthones; noriridoids; and polyphenols. This plant is known for his antimicrobial, anti-inflammatory, anti-allergic, immunostimulant, antidiabetic, anticancer, anti-oxidant, and anti-protozoan activities. It also possesses the ovicidal and larvicidal activity against Culex quinquefasciatus and Aedes aegypti; anti-infective activity, anti-angiogenic activity, and hepato-renal protective activity $[65,66]$.

\section{Acacia arabica \\ 1. Kingdom: Plantae \\ 2. Family: Mimosaceae \\ 3. Genus: Acacia \\ 4. Species: A. Arabica.}

A. arabica is a multipurpose tree, found widely distributed in tropical and subtropical regions of India, Sri Lanka, Australia, Africa, and Egypt. A. arabica is a perennial tree which usually grows up to $2.5-10 \mathrm{~m}$ tall. Thin, dark reddish-brown bark is present with purple-brown branches where the leaves grow up to 30-40 mm long. Golden yellow flowers are present with straight pod, and the seeds are found to be round in shape. The yellow color gum is secreted from the cuts of the bark where this has various medicinal properties [67] and hence used to treat diarrhea and dysentery when mixed along with quinine, also can be applied to the burns. Almost all parts of A. arabica is used for medicinal purposes where the leaves are used to treat ulcers; bark is used to treat gonorrhea, leukorrhea, as a mouthwash, for eye conjunctivitis; roots are used to reduce burning sensation of the skin [68]. The irular tribes who reside in Redhills, Tamil nadu, uses the bark of $A$. arabica as a remedy for tooth problems [69]. The phytochemical studies of A. arabica prove the presence of tannins, terpenoids, alkaloids, glycosides, and saponins $[68,70]$. Studies reveal that $A$. arabica is involved in various activities such as antidiabetic, antihyperlipidemic, antioxidant [71], anticancer, antimutagenic, anti-pyretic, antiplasmodial, antimicrobial, antihypertensive, and as antispasmodic [72].

\section{Ficus religiosa}

1. Kingdom: Plantae

2. Family: Moraceae

3. Genus: Ficus

4. Species: F. religiosa.

F. religiosa also was known as the Bodhi tree is considered as the sacred tree and found in India, Nepal, Thailand, Pakistan, and Israel. F. religiosa is a $20 \mathrm{~m}$ tall deciduous tree with grayish bark and alternate arrangement of dark green leaves. Sessile axillary flowers are found in the month of February. The green colored fruits are in round shape which turns to purple color with red dots once matured [57,73]. In ethnomedicine, its leaf extract along with honey is used to treat asthma, cough, diarrhea, migraine, eye troubles, toothache, and sexual disorders. The fruit paste is applied on the burns to heal the wounds. The stem bark acts as antiseptic, antidote, and astringent, and its aerial root juice finds a remedy to menstrual problems [74]. This plant has great ethnomedicinal value and is used by the Dimasa tribe of Assam where its root extract is used in the treatment of jaundice [75]. Phenols, tannins, steroids, alkaloids and flavonoids, Vitamin K, n-octacosanol, methyl oleanolate, lanosterol, stigmasterol, lupen-3-one, $\beta$-sitosterylD-glucoside, phytosterolin, albuminoids, caoutchoue, kaempeferol, quercetin, and myricetin, phytosterols, bergapten begaptol, and linoleic acid are the phytochemical constituents of this plant [76]. The presence of various chemical constituents makes the plant to be involved in antidiabetic, antimicrobial, antiviral, anti-inflammatory, anti-asthmatic, anticonvulsant, parasympathetic modulatory, estrogenic, antitumor, antiulcer, antianxiety, and antihelmintic activities [76-78].

\section{Cassia auriculata}

1. Kingdom: Plantae

2. Family: Caesalpiniacea

3. Genus: Cassia

4. Species: C. auriculata.

C. auriculata also known as Tanner's cassia is inherent to India and Srilanka, and it is prominently found in South India throughout the year. These are ornamental shrubs with yellow colour flowers. Almost all parts of the plant are known for its medicinal values such as astringent properties of the bark, anthelminthic properties of the fruits and leaves, ophthalmology issues relieving property of seeds, skin diseases relieving property of root, and antidiabetic property of the flowers $[79,80]$. The Paliyan tribes of the Sirumalai hills in Southern India used the juice of C. auriculata flowers to cure digestion problems in children [81]. Avarai panchanga choornam, an ayurvedic medicine consists of all five parts of the plants such as roots, leaves, flowers, barks and unripe fruits can be used to control diabetes [82]. The phytoconstituents present in C. auriculata are alkaloids, tannins, phenolic flavonoids, flavonoids, carbohydrates, proteins, steroids, terpenoids, and cardiac glycosides [83]. The plant is also known for its antimicrobial activity where the whole plant powder along with Tinospora cordifolia stem and leaves are mixed with cow's milk, used to treat diarrhea when taken internally. In addition, the flower juice of this plant is taken along with goat milk internally for venereal diseases. Among the other parts of this plant, the leaf and flowers act as a potent antimicrobial agent [84]. Other activities such as antioxidant [85], antipyretic, hepatoprotective, antiperoxidative, antidiabetic and antihyperglycemic are possessed by this plant [86].

\section{Punica granatum}

1. Kingdom: Plantae

2. Family: Lythraceae 
3. Genus: Punica

4. Species: P. granatum.

P. granatum is found in Iran, Afghanistan, India, Northern Africa, Caucasian, Tunisia, and Southern United States. In India, it is found widely in the Western Himalaya regions. The P. granatum known as the pomegranate is a small tree which can grow from 20 to $30 \mathrm{ft}$ high and found to be deciduous. It consists of red-brown bark with stiff, spiny branches; the leaves are narrow and lance-shaped with glossy in appearance; the flowers are brilliant red in colour and exist on the fruit; the fruits are round in shape around 2-5 in. wide with a prominent calyx at the base, the fruits are edible and takes 5-7 months to mature [87-90].

The sholaga tribes who live in the villages of Bargur in the Kathiri hills of Erode district, Tamil Nadu, India used its buds and fruits as a relief from dysentery [91]. The root and stem barks of this plant have astringent and anthelmintic activities; flowers can stop bleeding; fruits are sweet, sour and act as astringent laxative and diuretic; the seeds have astringent, cardiotonic, and stomachic properties. In the case of tapeworm infection root and stem bark is used; for vomiting, pitta, ophalmodynia, ulcers, and hydrocele flowers are used. To treat anemia, bronchitis, splenopathy and pectoral diseases fruits are used [92]. The substances such as alkaloids, triterpenoids, steroids, glycosides, saponins, flavonoids, tannins, carbohydrate, resins volatile oils, gums, and Vitamin C make the plant to have great medicinal importance $[93,94]$. And hence, the plant is considered to have antibacterial activity [95], anticandidal activity [96], antioxidant activity [97], anticarcinogenic activity, and anti-inflammatory activity. In addition, the plant is known as a remedy for osteoarthritis, cardiovascular disease, obesity, neonatal brain injury, Alzheimer's disease, and male infertility $[98,99]$.

\section{T. cordifolia}

1. Kingdom: Plantae

2. Family: Menispermaceae

3. Genus: Tinospora

4. Species: T. cordifolia.

T. cordifolia is dispersed throughout India, Srilanka, Burma, China, tropics of Australia, and Africa [100]. T. cordifolia is a large deciduous shrub with large branches and attractive greenish yellow unisexual flowers. This plant is well known as Guduchi has vast applications in ayurvedic medicine [101,102].

The whole plant decoction of this plant is used by the Dantewada tribe of Chhattisgarh to treat rheumatism, urinary problems, heart problems, and fever [103]. The stem is one of the main ingredient in many ayurvedic medicine, where the plant is known for its antidiabetic, antiallergic, antispasmodic, antileprotic, and antioxidant properties [104]. From the phytochemical analysis, it was found that the leaves of this plant contain $40.8 \mathrm{mg} / \mathrm{g}$ total phenolic content which is higher than the stem with $12.8 \mathrm{mg} / \mathrm{g}$. In addition, the presence of other chemical constituents such as alkaloids, terpenoids, steroids, glycosides, flavonoids, saponins, proteins, and carbohydrates makes the plant rich in medicinal values [105] (Table 1).

\section{CONCLUSION}

Green synthesis of AgNPsisa boon in the field of nanotechnologywhich is ecofriendly, cost-effective, and is a rapid process. The present documentation reveals that the folk medicine practices of the native tribes. In this present study, different tribal plants used by different tribal communities and the ability of these tribal plants to produce its respective AgNPs with a higher efficacy has been studied. In addition, the biogenic properties of these tribal plants were evaluated. All the tribal plants were found to have innumerable phytochemical constituents especially flavonoids, saponins, tannins, glycosides, steroids, phenols, and terpenoids which contributes for the synthesis of AgNPs from the metal salt, silver nitrate. Hence, this tribal plant-mediated synthesis of AgNPs as nanomedicine is suspected to resolve various difficulties in the pharmacological industries.

\section{ACKNOWLEDGMENTS}

The author would like to thank the University Grants Commission for providing the necessary funding under the scheme Rajiv Gandhi National Fellowship, 201516-RGNF-2015-17-SC-TAM-23441.

\section{AUTHORS CONTRIBUTION}

1. Anju K: The main author of the work is currently doing project on tribal plants and their inborn microbial activities and came up with the structure and model of the manuscript.

2. Anitha Jegadeeshwari L researches about the novel tribal plants in and around the area for antimicrobial activities. It promotes a better understanding of the native plants and their inborn therapeutic values. The author has contributed in language correction and in formulating reference session.

3. Vidhya Lakshmi D is a Research scholar at Department of Chemical Engineering, AC Tech, Anna University, Chennai. Her field of interest includes Chemical engineering applications in wastewater treatment, solid waste management, Leachate treatment and Management. Formatting of table, font reference has been done by this scholar.

4. Nagendra Gandhi N: Corresponding Author is the project mentor. $\mathrm{He}$ is the Professor and Head of Chemical engineering department, ACT Campus, Anna University, Chennai. His areas of interest include Extraction, Green Technology, Hydrotrophy, Environmental studies, Mass transfer, separation technologies. He has more than 70 journals published and has presented at many national and international conferences. He has conducted many workshops.

\section{CONFLICT OF INTEREST}

None declared.

\section{REFERENCES}

1. Ebrahiminezhad A, Raee MJ, Manafi Z, Jahromi AS, Ghasemi Y Ancient and novel forms of silver in medicine and biomedicine. J Adv Med Sci Appl Technol 2016;2:122-8.

2. Jefferson W. Colloidal silver today. The All-Natural Wide-Spectrum Germ Killer. Summertown TN, USA: Healthy Living Publication; 2003. p. 63.

3. Brave GM, Mashru M, Jagtap C, Patgiri BJ, Prajapati PK. Therapeutic potentials of metals in ancient India: A review trough Charaka Samhita. J Ayurveda Intrgr Med 2011;2:55-63.

4. Antony E, Sathiavelu M, Arunachalam S. Synthesis of silver nanoparticles from the medicinal plant Bauhinia acuminata and Biophytum sensitivum-a comparative study of its biological activities with plant extract. Int J Appl Pharm 2017;1:22-9.

5. Iravani S, Korbekandi H, Mirmohammadi SV, Zolfaghari B. Synthesis of silver nanoparticles: Chemical, physical and biological methods. Res Pharm Sci 2014;9:385-406.

6. Salata O. Applications of nanoparticles in biology and medicine. J Nanobiotechnol 2004;2:3.

7. Ahmed N, Fessi H, Elaissari A. Theranostic applications of nanoparticles in cancer. Drug Discov Today 2012;17:928-34.

8. Hamsika M, Gowda DV,Vindru J, Moin A. Nanotechnology for ophthalmic preparations. Int J Curr Pharm Res 2016;8:5-11.

9. Ammer MR, Zaman S, Khalid M, Bilal M, Erum S, Huang D, et al. Optimization of antibacterial activity of Eucalyptus tereticornis leaf extracts against Escherichia coli through response surface methodology. J Radiat Res Appl Sci 2016;9:376-85

10. Prow TW, Grice JE, Lin LL, Faye R, Butler M, Becker W, et al. Nanoparticles and microparticles for skin drug delivery. Adv Drug Deliv Rev 2011;63:470-91.

11. Hemant K, Raizaday A, Sivadasu P, Uniyal S, Kumar SH. Cancer nanotechnology: Nanoparticulate drug delivery for the treatment of cancer. Int J Pharm Pharm Sci 2015;7:40-6.

12. Banjare J. Application of nanotechnology in food technology and targeted drug therapy for prevention of obesity: An overview. J Crit Rev 2017;4:7-11.

13. Qu X, Alvarez PJ, Li Q. Applications of nanotechnology in water and wastewater treatment. Water Res 2013;47:3931-46.

14. Wong YW, Yuen CW, Leung MY, Ku SK, Lam HL. Selected applications of nanotechnology in textiles. Autex Res J 2006;6:1-8.

15. Khot LR, Sankaran S, Maja JM, Ehsani R Schuster EW. Applications of nanomaterials in agricultural production and crop protection: A review. 
Crop Protect 2012;35:64-70.

16. Mody VV, Siwale R, Singh A, Mody HR. Introduction to metallic nanoparticles. J Pharm Bioallied Sci 2010;2:282-9.

17. Rao CN, Kulkarni GU, Thomas PJ, Edwards PP. Metal nanoparticles and their assemblies. Chem Soc Rev 2000;29:27-35.

18. Sreeprasad TS, Pradeep T. Noble Metal nanoparticles. Springer Handbook of nanomaterials. Berlin, Germany: Springer-Verlag; 2013. p. 303-88.

19. Kaviya S, Santhanalakshmi J, Viswanathan B. Green synthesis of silver nanoparticles using Polyalthia longifolia leaf extract along with D-sorbitol: Study of antibacterial activity. J Nanotechnol 2011;2011:1- 5

20. Li J, Zhao T, Chen T, Liu Y, Ong CN, Xie J, et al. Engineering noble metal nanomaterials for environmental applications. Nanoscale 2015;7:7502-19.

21. Wang S, Zhang D, Ma Y, Zhang H, Gao J, Nie Y, et al. Aqueous solution synthesis of pt-M (M = fe, co, ni) bimetallic nanoparticles and their catalysis for the hydrolytic dehydrogenation of ammonia borane. ACS Appl Mater Interfaces 2014;6:12429-35.

22. Wen M, Cui Y, Kuwahara Y, Mori K, Yamashita H. Non-noble-metal nanoparticle supported on metal-organic framework as an efficient and durable catalyst for promoting $\mathrm{H} 2$ production from ammonia borane under visible light irradiation. ACS Appl Mater Interfaces 2016;8:21278-84.

23. Searle AB. The use of colloids in health and Disease. J Chem Technol Biotechnol 1920;39:211-3.

24. Noori MT, Jain SC, Ghangrekar MM, Mukherjee CK. Biofouling inhibition and enhancing performance of microbial fuel cell using silver nano-particles as fungicide and cathode catalyst. Bioresour Technol 2016;220:183-9.

25. Desireddy A, Conn BE, Guo J, Yoon B, Barnett RN, Monahan BM, et al. Ultrastable silver nanoparticles. Nature 2013;501:399-402.

26. Jang MH, Bae SJ, Lee SK, Lee YJ, Hwang YS. Effect of material properties on stability of silver nanoparticles in water. J Nanosci Nanotechnol 2014;14:9665-9.

27. Ajmal CM, Menamparambath MM, Choi HR, Baik S.Extraordinary high conductivity of flexible adhesive films by hybrid silvernanoparticle nanowires. Nanotechnology 2016;27:225603.

28. Dinh DA, Hui KS, Hui KN, Cho YR, Zhou W, Chun HH. Green synthesis of high conductivity silver nanoparticles- reduced graphene oxide composite films. Appl Surf Sci 2014;298:62-7.

29. Jiang ZJ, Liu CY, Sun LW. Catalytic properties of silver nanoparticles supported on silica spheres. J Phys Chem 2015;109:1730-5.

30. Ouay BL, Stellacci F. Antibacterial activity of silver nanoparticles: A surface science insight. Nanotoday 2015;10:339-54.

31. Mallmann EJ, Cunha FA, Castro BN, Maciel AM, Menezes EA, Fechine PB. Antifungal activity of silver nanoparticles obtained by green synthesis. Rev I Med Trop 2015;57:165-7.

32. Galdiero S, Falanga A, Vitiello M, Cantisani M, Marra V, Galdiero M, et al. Silver nanoparticles as potential antiviral agents. Molecules 2011;16:8894-918

33. Khandelwal N, Kaur G, Kumar N, Tiwari A. Application of silver nanoparticles in viral inhibition: A new hope for antivirals. Dig J Nanomater Biostruct 2014;9:175-86.

34. Lara HH, Ayala-Nuñez NV, Ixtepan-Turrent L, Rodriguez-Padilla C. Mode of antiviral action of silver nanoparticles against HIV-1. J Nanobiotechnol 2010;8:1.

35. Hebeish A, El-Rafie MH, El-Sheikh MA, Seleem AA, El-Naggar ME. Antimicrobial wound dressing and anti-inflammatory efficacy of silver nanoparticles. Int J Biol Macromol 2014;65:509-15.

36. Prasad SR, Elango K, Chellakumari DS, Dharani S. Preparation. Characterization and Inflammatory Activity of Chitosan Stabilized Silver Nanoparticles. Research J Pharma Dosage Forms and Tech 2013;5:161-7.

37. Wong KK, Cheung SO, Huang L, Niu J, Tao C, Ho CM, et al. Further evidence of the anti-inflammatory effects of silver nanoparticles. ChemMedChem 2009;4:1129-35.

38. Benn T, Cavanagh B, Hristovski K, Posner JD, Westerhoff. The realease of nanosilver from consumer products used in the home. J Environ Qual 2010;39:1875-82.

39. Kessler R. Engineered nanoparticles in consumer products: Understanding a new ingredient. Environ Health Perspect 2011;119:a120-5.

40. Ahmed S, Ahmad M, Swami BL, Ikram S. A review on plants extract mediated synthesis of silver nanoparticles for antimicrobial applications: A green expertise. J Adv Res 2016;7:17-28.

41. Huang J, Cao C, Yan C, Liu J, Hu Q, Guan W. Impacts of silver nanoparticles on the nutrient removal and functional bacterial community in verticle subsurface flow constructed wetlands. Bioresour Technol 2017;243:1216-26.

42. Gudikandula K, Maringanti SC. Synthesis of silver nanoparticles by chemical and biological methods and their antimicrobial properties. J Exp Nanosci 2017;11:714-21.

43. Natsuki J, Natsuki T, Hashimoto Y. A review of silver nanoparticles : Synthesis methods, properties and applications. Int J Mat Sci Appl 2015;4:325-32

44. Makarov VV, Love AJ, Sinitsyna OV, Makarova SS, Yaminsky IV, Taliansky ME, et al. "Green" nanotechnologies: Synthesis of metal nanoparticles using plants. Acta Nat 2014;6:35-44.

45. Bhosale RR, Kulkarni AS, Gilda SS, Aloorkar NH, Osmani RA, Harkare BR. innovative eco-friendly approaches for green synthesis of silver nanoparticles. Int J Pharm Sci Nanotech 2014;7:2328-37.

46. Kirthika P, Dheeba B, Sivakumar R, Abdulla SS. Plant mediated synthesis and characterization of silver nanoparticles. Int $\mathrm{J}$ Pharm Pharm Sci 2014;6:304-10.

47. Abdelmoteleb A, Salas BV, Beltran MC, Hernandez DD, Mendoza DG. Green synthesis of Silver nanoparticles using Pluchea sericea a native plants from Baja California, Mexico and their potential application as antimicrobials. Iran J Sci Technol Trans A Sci 2016:1-7 DOI: 0.1007/ s40995-016-0019-6.

48. Chaudhuri SK, Chandela S, Malodia L. Plant mediated green synthesis of silver nanoparticles using Tecomella undulata leaf extract and their characterization. Nano Biomed Eng 2016;8:1-8

49. Basu S. Dimensions of tribal health in India. Heal Popul Perspect 2000;23:61-70.

50. Rajora SC. Social Structure and Tribal Elite. Udaipur: Himanshu Publishers; 1987

51. Das S, Bose K. Adult tribal malnutrition in India: An anthropometric and socio-demographic review. Anthropol Rev 2015;78:47-65.

52. Durning AT. Guardians of the Land: Indigenous Peoples and the Health of the Earth. Washington, DC: Worldwatch Institute; 1992. p. 62.

53. Jegadeeshwari LA, Dharathi N, Lakshmi DV, Kumar EV, Gandhi NN. Tribal plants and their inborn antimicrobial activities. Asian J Pharm Clin Res 2017;10:31-7.

54. Sajem AL, Gosai K. Ethnobotanical investigations among the Lushai tribes in North Cachar Hills district of Assam, Northeast India. Indian J Tradit Knowl 2011;9:108-13

55. Dhayalan M, Jegadeeshwari LA, Gandhi NN. Biological activity sources from traditionally used tribe and herbal plants material. Asian J Pharm Clin Res 2015;8:11-23.

56. Sharma N, Dubey W. History and taxonomy of aegle marmelos: A review. Int J Pure Appl Biosci 2003;1:7-13.

57. Orwa C, Mutua A, Kindt R, Jamnadass R, Simons A. Agroforestree Database: A Tree Reference and Selection Guide Version 4.0. Kenya: World Agroforestry Centre; 2009

58. Sharma PC, Bhatia V, Bansal N, Sharma A. A review on bael tree. Indian J Nat Prod Resour 2007;6:171-8.

59. Kamble SY, Patil SR, Sawant SR, Sawant S, Pawar SG, Singh EA. Studies on plants used in traditional medicine by Bhilla tribe of Maharashtra. Ind J Trad Know 2009;9:591-8.

60. Dhankhar S, Ruhil S, Balhara M, Chhillar AK. Aegle marmelos (Linn.) Correa: A potential source of Phytomedicine. J Med Plants Res 2011;5:1497-507.

61. Sekar DK, Kumar G, Karthik L, Rao KV. A review on pharmacological and phytochemical properties of Aegle marmelos (L.) Corr. Serr. (Rutaceae). Asian J Plant Sci Res 2011;1:8-17.

62. Benoy GK, Animesh DK, Aninda M, Priyanka DK, Sandip H. An overview on Andrographis paniculata (burm. F.) Nees. Int J Res Ayurveda Pharm 2010;3:752-60.

63. Hossain MS, Urbi Z, Sule A, Hafizur Rahman KM. Andrographis paniculata (Burm. F.) wall. Ex nees: A review of ethnobotany, phytochemistry, and pharmacology. Sci World J 2014;2014:274905.

64. Rajalakshmi P, Pugalenthi M, Vadivel V. Traditional knowledge on medicinal plants used by the Irular tribe of Kadambur hills, Erode district, Tamil Nadu, India. J Med Plants Stud 2016:4:14-7.

65. Joselin J, Jeeva S. Andrographis paniculata: A review of its traditional uses, phytochemistry and pharmacology. Med Aromat Plants 2014;3:1- 15 .

66. Okhuarobo A, Falodun JE, Erharuyi O, Imieje V, Falodun A, Langer P. Harnessing the medicinal properties of Andrographis paniculata for diseases and beyond: A review of its phytochemistry and pharmacology. Asian Pac J Trop Dis 2014;4:213-22.

67. Rajvaidhya S, Nagori BP, Singh GK, Dubey BK, Desai P, Alok S, et al. 
A review on Acacia arabica- an Indian medicinal plant. Int J Pharma Sci Res 2012;3:1995-2005

68. Farzana M, Tharique I, Sultana A. A review of ethnomedicine, phytochemical and pharmacological activities of Acacia nilotica (Linn) willd. J Pharm Phytochem 2014;3:84-90.

69. Bosco FG, Arumugam R. Ethnobotany of irular tribes in redhills, Tamil Nadu, India. Asian Pac J Trop Dis 2012;2:874-7.

70. Mohammad R, Shariq S, Roohi Z, Malik I. Bark of Acacia arabica-A nature 's Gift : An Overview. Int Res J Med Sci 2014;2:20-4.

71. Hegazy GA, Alnoury AM, Gad HG. The role of acacia arabica extract as an antidiabetic, antihyperlipidemic, and antioxidant in streptozotocininduced diabetic rats. Saudi Med J 2013;34:727-33.

72. Ali A, Akhtar N, Khan BA, Khan MS, Rasul A, Zaman SU, et al. Acacia nilotica : A plant of multipurpose medicinal uses. J Med Plants Res 2012;6:1492-96.

73. Galil J. Ficus religiosa L.-the tree splitter. Bot J Linn Soc 1984;88:185- 203.

74. Kunwar RM, Bussmann RW. Ficus (Fig) species in Nepal : A review of diversity and indigenous uses. Lyonia 2006;11:85-97.

75. Nath M, Dutta BK, Hajra PK. Medicinal plants used in major diseases by dimasa tribe of barak valley. J Assam Sci Soc 2011;7:18-26.

76. Chandrasekar SB, Bhanumathy M, Pawar AT, Somasundaram T. Phytopharmacology of ficus religiosa. Pharmacogn Rev 2010;4:195-9.

77. Iqbal Z, Nadeem QK, Khan MN, Akhtar MS, Waraich FN. In vitro anthelmintic activity of Allium sativum, Zingiber officinale, Curcurbita Mexicana and Ficus religiosa. Int J Agric Biol 2011;3:454-7.

78. Singh D, Singh B, Goel RK. Traditional uses, phytochemistry and pharmacology of Ficus religiosa: A review. J Ethnopharmacol 2011;134:565-83.

79. Dulberger R. The floral biology of Cassia didymobotrya and $C$. auriculata. (Caesalpiniaceae). Am J Bot 1980;68:1350-60.

80. Siva R, Krishnamurthy KV. Isoenzyme diversity in Cassia auriculata L. Afr J Biotechnol 2005;4:772-5.

81. Karuppusamy S. Medicinal plants used by Paliyan tribes of Sirumalai hills of southern India. Nat Prod Rad 2007;6:436-42.

82. Dama GY, Rao ME. Anti-diabetic activity of Cassia auriculata (Linn) wall, seeds on streptozotocin induced diabetic rats. J Nat Prod 2011;2:36-51

83. Veerachari U, Bopaiah AK. Phytochemical investigation of the ethanol, methanol and ethyl acetate leaf extracts of six Cassia species. Int $\mathbf{J}$ Pharma Biosci 2012;3:260-70.

84. Duraipandiyan V, Ayyanar M, Ignacimuthu S. Antimicrobial activity of some ethnomedicinal plants used by paliyar tribe from Tamil Nadu, India. BMC Complement Altern Med 2006;6:35

85. Anusha C, Sampathkumar P, RamKumar L. Antibacterial and antioxidant activities in Cassia auriculata. Global J Pharmacol 2009:3:127-30

86. Murugan T, Wins JA, Murugan M. Antimicrobial activity and phytochemical constituents of leaf extracts of Cassia auriculata. Indian J Pharm Sci 2013;75:122-5.
87. Narzary D, Mahar KS, Rana TS, Ranade SA. Analysis of genetic diversity among wild pomegranates in Western Himalayas, using PCR methods. Sci Hortic 2009;121:237-42.

88. Samant SS, Dhar U. Diversity, endemism and economic potential of wild edible plants of Indian Himalaya. Int J Sust Dev World 2009;4:179- 91 .

89. Kumari A, Dora J, Kumar A, Kumar A. Pomegranate (Punica granatum)-Overview. Int J Pharm Chem 2012;1:1218-22

90. Mars M, Marrakchi M. Diversity of pomegranate (Punica granatum L.) germplasm in Tunisia. Genet Resour Crop Evol 2009;46:461-7.

91. Venkatachalam K, Ramasamy D, Sundaramurthy R. Ethnomedicnal study on tribal area of Kathiri Hills in Erode district of Tamilnadu, India. Cent Eur J Exp Bio 2015;4:20-6.

92. Chanda S, Kaneria M. Indian nutraceutical plant leaves as a potential source of natural antimicrobial agents. Science Against Microbial Pathogens: Communicating Current Research and Technological Advances. Spain: Fomatex Research Center Publication; 2011. p. 1251-9.

93. Bhandary SK, Kumari NS, Bhat VS, Sharmila KP, Bekal MP. Preliminary phytochemical screening of various extracts of Punica granatum peel, whole fruit and seeds. Nitte Univ J Healt Sci 2012;2:34-

94. Opara LU, Al-Ani MR, AL-Shuaibi YS. Physio-chemical properties, Vitamin $\mathrm{C}$ content, and antimicrobial properties of Pomegranate fruit (Punica granatum L.). Food Bioprocess Tech 2009;2:315-21.

95. Prashanth D, Asha MK, Amit A. Antibacterial activity of Punica granatum. Fitoterapia 2011;72:171-3.

96. Nair R, Chanda S. Anticandidal activity of Punica granatum. exhibited in different solvents. Pharm Biol 2008;43:21-5.

97. Aqil F, Ahmad I, Mehmood Z. Antioxidant and free radical scavenging properties of twelve traditionally used Indian medicinal plants. Turk J Biol 2006;30:177-83.

98. Jurenka JS. Therapeutic applications of pomegranate (Punica granatum L.): A review. Altern Med Rev 2008;13:128-44.

99. Miguel MG, Neves MA, Antunes MD. Pomegranate (Punica granatum L.): A medicinal plant with myriad biological properties-A short review. J Med Plants Res 2010;4:2836-47.

100.Panchabhai TS, Kulkarni UP, Rege NN. Validation of therapeutic claims of Tinospora cordifolia: A review. Phytother Res 2008;22:425-41.

101. Saha S, Ghosh S. Tinospora cordifolia: One plant, many roles. Anc Sci Life 2012;31:151-9.

102. Sinha K, Mishra NP, Singh J, Khanuja SPS. Tinospora cordifolia (Guduchi), a reservoir plant for therapeutic applications: A Review. Indian J Tradit Knowl 2004;3:257-70.

103.Sahu PK, Masih V, Gupta S, Sen DL, Tiwari A. Ethnomedicinal plants used in the healthcare systems of tribes of Dantewada, Chhattisgarh India. Am J Plant Sci 2014;5:1632-43.

104. Singh SS, Pandey SC, Srivastava S, Gupta VS, Patro B, Ghosh AC. Chemistry and medicinal properties of Tinospora cordifolia (Guduchi). Indian J Pharmacol 2003;35:83-91.104.

105. Yadav RN, Agarwala M. Phytochemical analysis of some medicinal plants. J Phytol 2011;3:10-4. 